\title{
AN ANALYSIS OF DIRECTIVE SPEECH ACTS PRODUCED BY TEACHERS IN EFL CLASSROOMS
}

\author{
Putu Dinia Suryandani* and I Gede Budasi \\ Universitas Pendidikan Ganesha \\ Received on 19 June 2021 / Approved on 12 October 2021
}

\begin{abstract}
The teaching and learning process entails several encounters in which the teacher and students exchange a variety of utterances, particularly in language classes. Understanding language involves an understanding of pragmatics. Teaching and learning will be more successful if appropriate speech acts are used. Directive Speech Acts are a type of speech act that is frequently employed in classroom interactions. It is used by the teacher to give instruction, command the students to do something, limit the students' bad behavior, etc. This study aims at investigating the types of directive speech acts and analyzing the functions of the acts used by English teachers at SMKN 1 Sawan. The theory of directive acts classification adopted in this study is the theory proposed by Ibrahim (1993). Ibrahim's theory classified directive acts into six major types. They are requestive, question, requirement, prohibitive, permission and advisory. This research also focused on the functions of directive acts based on Amalsaleh, Yamini, and Yarmohammadi's (2004) theory. They are elicitation, instruction, advice, threat, and attention-getter. This research was a descriptive study with two teachers as the subjects of this research. Observation and recording were used as the technique in collecting the data. The validity of the data used is source and theory of triangulation. The results showed that the most frequent type of directive speech acts used by the teachers was question directive with occurance of 185 utterances $(46.95 \%)$. Teachers that employ the question directive encourage students to be interested in the world around them, to enhance their abilities and attitudes toward science, and to enhance their speech communication and critical thinking. The other functions of the acts were also identified in various types of the acts.
\end{abstract}

Keywords: classroom interaction, directive speech acts, teacher's utterance

\section{ABSTRAK}

Proses belajar mengajar memerlukan beberapa pertemuan di mana guru dan siswa bertukar berbagai ujaran, terutama di kelas bahasa. Memahami bahasa melibatkan pemahaman pragmatik. Pengajaran dan pembelajaran akan lebih berhasil jika tindak tutur yang tepat digunakan. Tindak tutur direktif adalah jenis tindak tutur yang sering digunakan dalam interaksi kelas. Digunakan oleh guru untuk memberi instruksi, memerintahkan siswa untuk melakukan sesuatu, membatasi perilaku buruk siswa, dll. Penelitian ini bertujuan untuk menyelidiki jenis-jenis tindak tutur direktif dan menganalisis fungsi dari tindakan yang digunakan oleh guru bahasa Inggris di SMKN. I Sawan. Teori klasifikasi tindakan direktif yang dianut dalam penelitian ini adalah teori yang dikemukakan oleh Ibrahim (1993). Teori Ibrahim mengklasifikasikan tindakan direktif menjadi enam jenis utama yaitu permintaan, pertanyaan, persyaratan, larangan, izin dan nasihat. Penelitian ini juga berfokus pada fungsi tindak direktif berdasarkan teori Amalsaleh, Yamini, dan Yarmohammadi (2004). Mereka adalah elisitasi, instruksi, saran, ancaman, dan penarik perhatian. Penelitian ini merupakan penelitian deskriptif dengan dua orang guru sebagai subjek penelitian. Teknik observasi dan pencatatan digunakan sebagai teknik pengumpulan data. Validitas data yang digunakan adalah triangulasi sumber dan teori. Hasil penelitian menunjukkan bahwa jenis tindak tutur direktif yang paling sering digunakan oleh guru adalah direktif pertanyaan dengan kemunculan 185 ucapan (46,95\%). Guru yang menggunakan arahan pertanyaan mendorong siswa untuk tertarik pada dunia di sekitar mereka, untuk meningkatkan kemampuan dan sikap mereka terhadap sains, dan untuk meningkatkan komunikasi ucapan dan pemikiran kritis mereka. Fungsi lain dari tindakan juga diidentifikasi dalam berbagai jenis tindakan.

Kata Kunci: interaksi kelas, tindak tutur direktif, ucapan guru

*Author(s) Correspondence:

E-mail: dinia@undiksha.ac.id 


\section{INTRODUCTION}

Communication is an important part of the teaching and learning process because it affects classroom interaction. The speaker seeks to transmit a certain goal or objective to the listener through communication. The message communicated must be properly comprehended by the hearer participating in the communication process, hence communication must be successful and efficient. The purpose of classroom interaction is to communicate thoughts, feelings, or ideas (Veysi \& Abbaszadeh, 2015). It will generate a harmonic teaching and learning interaction that runs in line with the strategy to be reached through appropriate communication activities (Sun, 2012). In a teaching and learning setting, social interactions between students and teachers, as well as among students themselves, that generally occur during smallgroup work and whole-class discussions, can lead to negotiation and co-construction of students' communication skills (Li \& Stylianides, 2017). A teacher's role as an instructor is one of them. This role may be seen when the instructor offered students instructions or explanations to do things like read a book, view a series of pictures, discuss a topic, or do an exercise, and then corrected the students' work. As seen, the teacher's common actions were commanding, delivering instructions, imposing requirements, and granting permission. It is undeniable that the teaching and learning process comprises several exchanges in which the instructor and students make a variety of utterances, particularly in language classes.

Directives are a type of communication that is regularly employed in the classroom (Saadatmandi, Khiabani, \& Pourdana, 2018). It is used by teachers to persuade students to perform something. Commanding, ordering, advising, requesting, warning, and other directive speech acts are utilized (Searle, 1979). The purpose of the teacher's directive speech actions is to assist and enhance the students' learning. It indicates that the hearer will behave in regard to every speaker's word in order to attain what he/she desires (Haryanto, 2018). It is very important to be used in classroom interaction by the teacher. The instructor can easily regulate the students' behavior in the classroom and know how to respond to unacceptable behavior, as well as ask the students to participate actively in the learning process.

There were just a few researchers that were interested in performing a study on the importance of studying directive speech acts especially in vocational school. This was the most important finding of the current study, and it was considered novelty of the research. However, studies into the implementation of directive speech acts in vocational school is rarely conducted since most researches concentrated on speech acts in general and just a few on directive speech acts. This study aims to examine the different forms of directive acts employed by teachers in the classroom during the teaching and learning process and to examine the functions of directive acts.

\section{LITERATURE REVIEW}

\section{Speech Acts}

Speech acts is one of the five major areas of pragmatics research. A philosopher, John L. Austin, originally introduced the notion of speech acts in his book How to Do Things with Words. Austin (1962) defines speech acts as any actions that is carried out by speaking things. One can compel people to do something by using their words. The locution refers to what is spoken, or the speech. The illocution is what the speaker means to express to the addressee (the purpose). The perlocution is the message that the addressee receives, his interpretation of what the speaker says. The illocution and perlocution are similar or almost identical if the communication is successful (Kreidler, 2002).

\section{a. Locutionary acts}

The production of utterances having a specific structure, meaning, and reference are referred to as locutionary acts. In other

\footnotetext{
*Author(s) Correspondence:

E-mail: dinia@undiksha.ac.id
} 
words, locutionary acts are concerned with an utterance's linguistic meaning or grammatical (or phonological) structure. The act of stating something is another name for this type of speech act (Rafli, 2018).

b. Illocutionary acts

Speakers engage in illocutionary acts when they say something (with the right purpose and in the right context), rather than when they achieve a specific result by saying something (Enyi, 2016). Illocutionary force or illocutionary function refers to the speaker's unique intent and the aim of expression. The theory was further modified by Searle (1979) in which he classified illocutionary acts into five speech acts categories, they are Directives, Representatives or Assertives, Commissives, Declaratives, and Expressives.

c. Perlocutionary acts

Speech acts that rely on the development of a certain impact are known as perlocutionary acts. The hearer is the one who creates this impact. There is an influence impact in perlocutionary because the speaker tries to persuade the listener to do what he or she wants (Rumaria, 2015). The phenomenon is known as the perlocutionary effect.

\section{Ibrahim's (1993) Directive Acts Classification}

Directives are illocutionary acts used by speakers to encourage the listeners to perform something. These actions communicate what the speaker wants, and the speaker uses the hearer to try to make the world suit the words (Yule, 1995). Furthermore, he defines directive speech as "utterances that are attempted by the speaker's attitude toward the action to be done by the hearer." Furthermore, directive speech acts convey the speaker's expectation of the listener's future behavior. Ibrahim (1993) studied that directive speech acts are classified into six types, namely, requestive, question, requirement, prohibitive, permissive, and advisory. Requestive shows that in saying something the speaker wants the partner to do something as said. Question is a request which in this case has a special understanding that the speaker asks for information from his partner through questions. In term of requirements, the speaker and the addressee, could do some interaction like command, want, direct, instruct, demand, dictate, regulate, and require. In utterance or producing speech, the speaker prohibits the addressee to do something so that there are two commonly conclude as prohibitives act like prohibit and limit. Permissives are used by speakers to show their beliefs towards the addressee in carrying out an action. Directive acts also have some specific function. According to Amalsaleh et al., (2004), there are five functions of directive acts namely elicitation, instruction, attentiongetter, suggestion, tactfulness, advice, conditional, and threat.

\section{RESEARCH METHODOLOGY}

This study was conducted at SMKN 1 Sawan, Menyali village, Buleleng regency. The data gathered was analyzed descriptively and this study implementedthe techniques of data analysis proposed by Lacey \& Luff (2009). Transcribing, organizing the data, familiarization, coding, and themes were techniques in analyzing data. The research was conducted by using descriptive qualitative approach as Creswell (2009) states that the analysis of the data is presented in the form of narrative or words instead of the number. The data were collected during the teaching and learning process through observation and recording.

The sources of data in this study were two English teachers in SMK Negeri 1 Sawan. The teachers were a male and a female which had been chosen by the researcher since their experience in teaching was more than five years. A video recorder was used to record the interaction in the classrooms especially teacher's utterances. The data were collected during English lessons of the first semester. Each teacher was being observed 6 times until the data saturated. Observation sheets were

\footnotetext{
*Author(s) Correspondence:

E-mail: dinia@undiksha.ac.id
} 
used to help the researcher to categorize the type and function of directive speech acts. Interview guide was used to get a clearer information of teacher's intention. The primary instrument in this research was the researcher herself. The researcher was involved in all process of the research started from the data design until the data report. The secondary instrument was tables or data sheets. To record the activity, the researcher used a video recorder particularly to record the interaction in the classroom including teacher's utterances. In addition, observation sheets or observation checklists were also used in collecting the data. The collected data were analyzed using Miles, Huberman, \& Saldana's (1994) terminologies namely, data collection, data reduction, data display, and conclusion drawing/ verification.

\section{FINDINGS AND DISCUSSION}

Types of directive speech acts produced by the English teachers of SMKN 1 Sawan

The directive speech acts types were identified based on the classification of Ibrahim's (1993) directive speech acts. The distribution of the types by the English teachers is illustrated in Table 1.

Table 1. Types of Directive Acts

\begin{tabular}{|l|l|l|}
\hline $\begin{array}{c}\text { The Type of } \\
\text { Directive Acts }\end{array}$ & Frequency & Percentage \\
\hline (Ibrahim, 1993) & (f) & $(\%)$ \\
\hline Requestive & 11 & $2.79 \%$ \\
\hline Question & 185 & $46.95 \%$ \\
\hline Requirement & 144 & $36.55 \%$ \\
\hline Prohibitive & 14 & $3.55 \%$ \\
\hline Permissive & 27 & $6.85 \%$ \\
\hline Advisory & 13 & $3.30 \%$ \\
\hline Total & 394 & $100.00 \%$ \\
\hline
\end{tabular}

Table 1 shows the six types of Ibrahim's directive speech acts performed by the English teacher during the English teaching and learning process in EFL classroom. They were Requestive, Question,
Requirement, Prohibitive, Permissive, and Advisory. The table also shows that the most common speech acts employed by teachers were question directives, which accounted for 185 utterances (46.95\%). Meanwhile, the least directive speech acts produced by English teachers were requestive, which appeared in just 11 utterances, representing for 2.79 percent of all utterances. Throughout the data analysis, directives are speech acts that are used to persuade the listener to do specific activities.

The result also found the functions of directive speech acts were determined using Amalsaleh et al.'s directive speech acts classification. The distribution of the types by the English teachers is illustrated in Table 2.

Table 2. Functions of Directive Acts

\begin{tabular}{|c|c|c|c|c|c|c|}
\hline \multirow{2}{*}{$\begin{array}{l}\text { The Type of } \\
\text { Directive } \\
\text { Acts }\end{array}$} & \multicolumn{6}{|c|}{ Function } \\
\hline & El & In & Ad & $\mathbf{T r}$ & $\begin{array}{c}\text { At } \\
\mathbf{t}\end{array}$ & \\
\hline $\begin{array}{l}\text { Requestive } \\
(R q)\end{array}$ & & 1 & & & & \\
\hline $\begin{array}{l}\text { Question } \\
(Q u)\end{array}$ & 80 & & & & & \\
\hline $\begin{array}{l}\text { Requirement } \\
(\mathrm{Re})\end{array}$ & & 30 & & & & \\
\hline $\begin{array}{l}\text { Prohibitive } \\
(\mathrm{Pr})\end{array}$ & & 1 & & & & \\
\hline $\begin{array}{l}\text { Permissive } \\
(\mathrm{Pe})\end{array}$ & & 7 & & & & \\
\hline Advisory $(A d)$ & & & 2 & & & \\
\hline $\begin{array}{l}\text { Number of } \\
\text { Occurrence }\end{array}$ & 82 & 92 & 3 & & & 94 \\
\hline Total & $\begin{array}{l}46 . \\
19 \\
\%\end{array}$ & $\begin{array}{l}48 . \\
73 \\
\%\end{array}$ & $\begin{array}{l}3.3 \\
0 \\
\% \\
\end{array}$ & $\begin{array}{l}0.5 \\
1 \\
\% \\
\end{array}$ & $\begin{array}{l}1.2 \\
7 \\
\% \\
\end{array}$ & $\begin{array}{l}100 . \\
00 \\
\%\end{array}$ \\
\hline
\end{tabular}

The findings were only elicitation, instruction, threat, advice and attention-getter. It showed that the functions of directive acts found were 182 utterances as elicitation (46.19\%), 192 utterances as instruction (48.73\%), 13 utterances as advice (3.30\%), 2 utterances as threat $(0.51 \%)$ and 5 utterances as attention-getter (1.27\%).

*Author(s) Correspondence:

E-mail: dinia@undiksha.ac.id 
1) Requestive

\section{DS-4/T1/M-2/034 Just raise your hand, we are absolutely okay to make mistakes. Can you do that please?}

The teacher requested the students to raise their hand answering the question when the teacher were explaining recount text. This utterance was classified as requestive since the purpose of the teacher was to request the students to read their recount text about the last holiday.

\section{2) Question}

\section{DS-2/T2/M-1/001 Who's absent today?}

Due to several observations, teachers are commonly asking the students' attendance before starting the class. The teacher implied a question by using 'who' as a starting point of asking. It is confirmed that question directive usually appears with $5 \mathrm{~W}+1 \mathrm{H}$ question and arranged in an interogative form.

The same function of question in Amalsaleh et al., (2004) found was Elicitation.

\section{DS-5/T1/M-3/043 What do you think about it? Regular or irregular?}

The material taught by the teacher was about past tense. The students had to change the verb based on the suitable tenses. One student underlined word "choose". The teacher asked the rest of the students to think if it is "choose" that should be changed. The students answered that "choose" should be transformed into "chose". The teacher continued to ask their opinion about the answer whether it is regular or irregular verb. Then, all of them answered it was irregular verb.

Amalsaleh et al., (2004) further classify Question functioned as Threat.

DS-1/T1/M-1/071 Your sister had black tie. Why don't you ask your sister? Why don't you ask your sister?

During the lesson, the teacher often strolling around the class checking the uniform of the students. The teacher noticed one student did not wear the tie. He later asked him where is his tie and he said that his tie was lost. The teacher uttered that he should wear his sister's tie since he knew that his sister had been graduated. Since the student's expression was shocked and triggered, this utterance could be presented as a threat since the teacher stated those words by looking right at his students' face and touching his uniform.

According to the observation, the school was very concern of the completeness of their students performance and teacher had authority in disciplining the students who were out of the standard that in this case the teacher might threaten the student.

\section{3) Requirement}

DS-1/T1/M-1/018 Put it in the right order, do not step on it or you may broke it!

Since the teacher had a higher authority, it was possible for him to command the students directly to keep the class always clean by telling the students to take care of the cleaning equipment. Requirement can be marked by exclamation points (!).

Amalsaleh et al. (2004) put the same function of requirement in instruction

\section{DS-3/T2/M-2/007 Close your book first! Give me one example of asking direction. \\ The material was about asking} direction. When the teacher asked the students to give her the examples of expression used in asking direction, some students were busy opening their book tried to look for the material. The requirement also functioned as Attention-getter as:

\section{DS-1/T1/M-1/007 Please attention!}

The teacher just begun the class by checking the students' grooming. He found that one student wore different color of trousers. Then the teacher wanted everybody to listen to him by saying those words. He continued to tell the students that tomorrow everyone should wear uniform in a good order. By attracting students' attention, the teacher could give the lesson easily since everybody is focused on him. Attention-getter could be realized through question and requirement. It also can be used to control the students when they make such a noisy sound during the learning process.

\footnotetext{
*Author(s) Correspondence:

E-mail: dinia@undiksha.ac.id
} 
4) Prohibitive

DS-5/T1/M-3/097

Next paragraph. How

about the others? Only few of you understand this? Why always Stefani, Ayu and Rudi answer it?

The utterance produced by the teacher was about to encourage the students to become more participating in the class. It seemed to look that only a few students diligently answered every question the teacher had asked. In order to be fair, when Stefani was raising her hand, the teacher limited her participation so that the other students are forced to answer the question.

\section{5) Permissive}

\section{DS-3/T2/M-2/014 Purnama, you can go outside.}

In the middle of explaining the material of Asking and Giving Direction, one students from OSIS asked the teacher to give some times for Purnama to go outside for the other duty. The teacher permitted Purnama to go outside the classroom.

\section{6) Advisory}

DS-2/T2/M-1/022 Ok for Soma maybe you have to make the conversation just how to asking direction. So the conversation is how to asking direction. Just asking for the place and where you friend wants to go.

The conversation delivered by Soma does not contain any requirement of what the teacher explained before. Then, the teacher advised Soma by giving him a deeper insight about how to write a conversation based on the instruction given.

In Amalsaleh et al., (2004), the function of Advisory was found in Advice

DS-5/T1/M-3/067 Finish ya the first paragraph. Then, the second paragraph. It is about your activity there. First, what is the activity here? You can make three or four sentences di paragraf kedua. Do you understand? Maybe first hiking, and then canyoning and then see the sunset. The last paragraph, what is the feeling after the holiday? Sad maybe when you lose something.
The students were asked to make a similar paragraph according to the instruction given by the teacher related to the sequences of the each paragraph. The teacher gave advice for the ideas that might be used in writing the paragraph.

As had been explained in the previous section, there are six types of directive speech acts produced by the teachers in the classroom interaction according to Ibrahim (1993) such as requestive, question, requirement, prohibitive, permissive, and advisory. Directives, due to their nature of being nonrefusable requests expect the hearer to conform. The hearer, however, if not familiar with the convention, might misinterpret the speaker's intention. A teacher, apart from other skills, needs to be conscious of different forms of utterance which may serve the same function, or different functions which may be expressed through one single form as it is proved by the teacher interview that had been conducted.

The directive speech act is a functional basic unit in communication, particularly in educational settings where the teacher acts as the instructor. According to the findings, the question type of directive speech act has become the most dominant, with the directive speech act of requirement coming in second. However, the finding of this study has similarities with Ibrahim (1993)'s statement (as cited in Yahya, 2013) asserting that question directive speech acts is frequently produced by the teacher during classroom interaction This results revealed that class engagement might be carried out through a conversation of questions and responses between the teacher and the students. The implementation of English directive speech acts based on type and function has attained $100 \%$ completion. It had been conducted proportionally where question directive was more dominant with $46.95 \%$. The teachers used directive speech acts for asking, requesting, complaining, giving, and demanding students' participation in the majority of the time of class interaction.

As the elicitation, the question directive speech acts performed the most

\footnotetext{
*Author(s) Correspondence:

E-mail: dinia@undiksha.ac.id
} 
important function in the interaction. The teachers employed question tone, such as (Right?, Yes?, Finish? ), (2) interrogative phrases, such as (Is, Are, Do, Can, Did), and (3) question words, such as (What, Where, When, Who, Which, and How). The teachers employed verbal expressions like (Give Example!, Listen!) a lot in the requirement type of directives.

In this case, the findings would also be presented and linked to the findings of the other researcher's earlier work. According to Yahya (2013), the use of question is the most frequent (315 out of 826 ) of the other directive functions in classroom interaction. It indicates the use of questions in directive speech acts attempts to increase student participation in the teaching and learning process.

In addition, Elicitation function appeared 182 times $(46.19 \%)$ through realization of question, requirement, and prohibitive while Instruction function appeared 192 times $(48.73 \%)$ realized from all the types of directive. As a consequence, the study's findings suggested that the reasonable interpretation of utilizing a question directive speec act was related to the effectiveness and efficiency of time spent in an interaction, and that it was socially permitted. While students may confront challenges in class, they often require assistance to complete the essential work, and they may be hesitant to ask for assistance in the absence of a somewhat welcoming environment. The adoption of Scientific Approach in Permendikbud of 2013 curriculum was highlighted by the predominance of question type directives. The scientific approach is a science process-based approach that is done through the process of observing, questioning, exploring/ experimenting, associating, and communicating. It indicates that asking students questions is a required practice. Since directive acts are essentially used to give a command to someone to do something, the decision to use question directive instead of requirement type was made because question directive makes learners curious about the world around them, improves skills and exhibits more positive attitudes toward science, and improves their oral communication.

Regarding the directive forms used in the classrooms, along with their functions, the findings of this study reveal the attitude of the teachers towards the students. That is to say the findings suggest that the observed classes seem to be in favor of to students classes as advocated by Amalsaleh et al. (2004) in which the teacher's status is high and (s)he is in authority. The tendency of teachers in directing the students can be characterized by using high percentage of instruction (48.73\%) as the most dominant function. This suggests that teachers tend to believe that $\mathrm{s} / \mathrm{he}$ is the authority figure and the whole process of instruction is to the benefit of the students. In such classes, the teacher has the right to ask students questions or give them instructions.

The finding was related with the previous study that has been done by the other researcher. A research conducted by Putri (2015) that the result found function of teachers' directives speech acts were perform a specific action, to assess students' information about a specific task, to request permission, and to direct students' attention during the teaching-learning process. Also, it answered the study conducted by Sari (2018) where requests, requirements, and questions are three sorts of directive speech acts that are frequently employed by teachers. Furthermore, Etikasari (2012) revealed order, requirements, requestives, invitation, prohibitives, suggestion, and persuasion are found in the introduction activity, core, and closing. Meanwhile, Wulansari \& Suhartini (2015) found that the most common function of directives utilized is elicitation, with 108 instances (44 percent), but the most dominating function in this study is instruction.

Furthermore, because the instructor and students are separated by a vertical distance, the students are obligated to obey or carry out the teacher's wishes. This is the indication that requestive proposed by the teachers barely appear which ranked as the least type of directives used. For instance, in the case of interrogative or elicitation, it was

\footnotetext{
*Author(s) Correspondence:

E-mail: dinia@undiksha.ac.id
} 
noticed that whenever there were not appropriate answers, on the part of students, the same questions were repeated louder and in more emphasized ways. This shows that teachers expect students to comply in answering the questions. Regarding different forms which directives may take, it is argued that although the primitive form of a directive can be expressed via various other forms.

The teachers were regarded as one of the biggest influences in conducting the interaction in language teaching and learning. The use of directive speech acts was therefore strongly linked to the circumstances as well as the speakers' social cultures. As a result of this finding, the use of directive speech acts like question and requirement was heavily influenced by the circumstances of the situation as well as the context of the speech act speakers' social values and cultures. In this case, the teacher represented the speaker's higher social rank, while the students represented the speaker's lower social status.

The majority of the utterances made by teachers in the classroom were on the type and function of directive acts which signifies that the language teaching and learning process was carried out in an engaging manner. The role of the teacher as a resource since much of the classroom activities consisted of complementing tasks and conducting exercises, the teacher utilized directives to urge the students to take action (Schleppegrell, 2004). Making a distinction between an order and a request, in terms of their "preparatory condition," Searle (1969) purports that the speaker giving direction must be in a position of authority over the addressee. Moreover, while a request is typically expressed in instruction, stating the speaker's desire.

\section{CONCLUSION AND SUGGESTIONS}

\section{Conclusion}

This research is concerned with pragmatic analysis of the use of directive acts in teaching and learning process by the teacher towards the students at SMK Negeri 1 Sawan.
In line with the objective of the research in order to identify the types of directive acts and to explain the function of directive acts used by the teachers during teaching and learning process, the research results can be concluded as follows: the teachers of SMK N 1 Sawan produced six types of directive acts, they were requestive, question, requirement, prohibitive, permissive and advisory. It contained 11 utterances as requestive $(2.79 \%), 185$ utterances as question (46.95\%), 144 utterances as requirement (36.55\%), 14 utterances as prohibitive (3.55\%), 27 utterances as permissive (6.85\%) and 13 utterances as advisory (3.30\%). From 394 utterances produced by the teachers during the teaching and learning process, question directive was the most dominant type which was used 185 times which represented $(46.95 \%)$. In addition, the functions that used by the teachers were elicitation, instruction, threat, advice and attention-getter. Although directives, in essence, expect a non-verbal behavior from the hearer, it is of fundamental importance for the speaker to choose among different forms of directives, the one which suits the circumstance best and furthermore, poses the least possibility of offense to the hearer(s). In other words, the speaker, in this case, a teacher has to express his or her intention appropriately with regards to the hearer's age, rank, and sex, among others. The multifunctionality of utterances is known to be an important obstacle in learning a foreign language or in appropriately translating an utterance from the source language to the target one or vice versa. Thus, identifying the forms and functions of directives in SMKN 1 Sawan and their relationship in specific contexts can shed light on teaching English as the Foreign Language.

\section{Suggestions}

For the students with language specification who are interested in conducting the research related to the pragmatics especially speech acts study are expected to explore and learn more about directive acts classification in accordance with various ideas of other experts since the directive acts always

\footnotetext{
*Author(s) Correspondence:

E-mail: dinia@undiksha.ac.id
} 
occur in teaching and learning process. Therefore, the students are expected to find out more about the types and the functions used by the teacher in the classroom.

\section{REFERENCES}

Amalsaleh, E., Yamini, H., \& Yarmohammadi, Y. (2004). Directives Used In University Classrooms. Journal of Literature and Language, 20-42.

Austin, J. L. How to do things with words, Clarendon Press. § (1962). Oxford.

Creswell, J. W. (2009). Research Design: Qualitative, Quantitative, and Mixed Methods Approaches. (M. P. Scott, Ed.). University of Nebraska-Lincoln: SAGE Publications, Inc.

Enyi, A. U. (2016). Rhetorical Diplomacy: A Study of Nigeria's President Muhammadu Buhari's Speech to The 70th Session of The United Nations General Assembly, 4(2), 38-52.

Etikasari, D. (2012). Tindak Tutur Direktif dalam Wacana Kelas (Kajian Mikroetnografi terhadap Bahasa Guru), (I).

Haryanto, M. H. (2018). Teacher' s Directive Expressions Analysis in English Teaching Classes. Lensa: Kajian Kebahasaan, Kesusastraan, Dan Budaya, 8(1), 22-42.

Ibrahim, A. S. (1993). Kajian Tindak Tutur. Usaha Nasional.

Kreidler, C. W. (2002). Introducing English Semantics. Routledge 11 New Fetter Lane, London EC4P 4EE.

Lacey, A., \& Luff, D. (2009). Qualitative Data Analysis. University of Nottingham: The NIHR RDS.

Li, H., \& Stylianides, A. J. (2017). An Examination of The Roles of The Teacher and Students during a Problem-Based Learning Intervention: Lessons Learned from a Study in a Taiwanese Primary Mathematics
Classroom.

https://doi.org/10.1080/10494820.201 7.1283333

Miles, M. B., Huberman, A. M., \& Saldana, J. (1994). Qualitative Data Analysis (Third). Sage Publications, Inc.

Rafli, Z. (2018). English Speech Acts of Illocutionary Force in Class Interaction. Advances in Language and Literary Studies, (c). Retrieved from

http://dx.doi.org/10.7575/aiac.alls.v.9n .3p. 113

Rumaria, C. (2015). An Analysis of Speech Acts in The Dead Poets Society. Yogyakarta State University.

Saadatmandi, M., Khiabani, S. M., \& Pourdana, N. (2018). Teaching English Pragmatic Features in EFL Context : A Focus on Request Speech Acts, 8(7), 829-835.

Sari, K. P. (2018). Teacher's Directive Speech Acts at Kindergarten School. VISION: Journal For Language and Foreign Language Learning, 7(1), 34-44.

Schleppegrell, M. J. (2004). The Language of Schooling: A Functional Linguistics Perspective. University of California, Davis: Lawrence Erlbaum Associates Publisher.

Searle, J. R. (1979). Expression and Meaning. Cambridge: University of Cambridge.

Sun, Z. (2012). An Empirical Study on New Teacher-student Relationship and Questioning Strategies in ESL Classroom Zuosheng. English Language Teaching, 5(7), 175-183. Retrieved from http://dx.doi.org/10.5539/elt.v5n7p175

Veysi, E., \& Abbaszadeh, F. (2015). The Communicative Function of Intonation Processing in English and PersianPerception of Implicit Directive Messages. International Journal of English Language \& Translation Studies, 3, 73-85.

Wulansari, Y., \& Suhartini, C. (2015). Directive Speech Acts Realization of Indonesian EFL Teacher. Journal of English Education, 3(2).

*Author(s) Correspondence:

E-mail: dinia@undiksha.ac.id 
Yule, G. (1995). Pragmatics. Oxford University Press.

*Author(s) Correspondence:

E-mail: dinia@undiksha.ac.id 